\title{
A Meta-Analysis of Workaholism
}

\author{
Avani S. Patel ${ }^{1}$, Mark C. Bowler ${ }^{2}$, Jennifer L. Bowler ${ }^{3} \&$ Scott A. Methe ${ }^{3}$ \\ ${ }^{1}$ comScore, Inc. USA \\ ${ }^{2}$ Department of Psychology, East Carolina University, Greenville, USA \\ ${ }^{3}$ East Carolina University, Greenville, USA \\ Correspondence: Mark C. Bowler, Department of Psychology, East Carolina University, Greenville, USA. \\ E-mail: bowlerm@ecu.edu
}

\author{
Received: January 31, $2012 \quad$ Accepted: March 23, $2012 \quad$ Published: June 1, 2012 \\ doi:10.5539/ijbm.v7n11p2 URL: http://dx.doi.org/10.5539/ijbm.v7n11p2
}

\begin{abstract}
This meta-analysis examines the relationship between workaholism and numerous work behaviors and outcomes in an attempt to a) derive a consensus regarding the current state of our understanding of this construct, and b) clarify the impact that the compulsion to work may have on an individual's life. Overall, based on data from 44 studies, results indicate that there is a considerable amount of variability between workaholism and work-related outcomes. Specifically, the two most established and reputable measures of workaholism, the Work Addiction Risk Test (WART) and the Workaholism Battery (WorkBat), appear to focus on uniquely different aspects of workaholism and were subsequently found to be differentially related to various work criteria. These findings suggest that a consistent definition and operationalization of workaholism is explicitly needed before further progress can be made.
\end{abstract}

Keywords: addiction, meta-analysis, workaholism

\section{Introduction}

The term workaholism was originally coined to describe an individual's deleterious compulsion to work (Oates, 1971). This impulse was initially considered a form of addiction that was equally as destructive as alcoholism; hence, Oates suggested the term workaholism. Over time the definition has been expanded to include not only the symptoms of harmed mental, physical, and social health typically associated with alcoholism (Porter, 1996), but also the specific personality characteristics that comprise the workaholic profile (Harpaz \& Snir, 2003; Scott, Moore, \& Miceli, 1997).This broadened conceptualization of workaholism- along with its association with personality and mental health - is considered to have a serious impact on both the personal and work lives of countless individuals (c.f. Booth-Kewley \& Friedman, 1987; Chamberlin \& Zhang, 2009; Clark, McEwen, Collard, \& Hickok, 1993).

Workaholism is problematic for everyone involved; negatively affecting not only workaholics, but also their employers, families, and society as a whole (Robinson, 2000, 2001; Salmela-Aro \& Nurmi, 2004). Although naïve interpretation of its meaning may lead many to initially believe that a workaholic is an asset to their organization, research has discovered evidence to the contrary. For example, Salmela-Aro and Nurmi (2004) noted that individuals who tend to work excessively- a hallmark behavior of workaholics - are at a higher risk of burnout. Subsequently, workaholics often experience emotional exhaustion, cynicism about their job, and dissatisfaction with their work accomplishments (Maslach \& Jackson, 1984), all of which decrease worker productivity (Liang \& Chu, 2009). Aside from negatively affecting effectiveness on the job, workaholism has also been shown to negatively impact an individual's family life. For example, Robinson (2001) noted that workaholism takes a significant toll on individuals' relationships with their spouses and negatively influences the development of their children. This subsequently engenders unsatisfactory relationships with family members due to the emotional and mental strains placed not only on the workaholic but also on his or her family members. Moreover, within our society workaholics are frequently rewarded for their work-related behaviors, thus perpetuating the behavior of existing workaholics and encouraging others to become workaholics under the societal label of virtue (McMillan \& Northern, 1995).Thus, workaholism is ultimately a societal predicament as much as an individual dilemma. The positive reception surrounding this disorder has created denial on the part of workaholics, and the lack of recognition of workaholism as an actual problem is fueling its perpetuation (Porter, 
1996).

Research also suggests that workaholism is associated with numerous life-affecting variables such as an individual's level of happiness (Schaufeli, Bakker, Van der Heijden, \& Prins, 2009), need for perfection (Burke \& Fiksenbaum, 2009), supervisor support and co-worker cohesion (Johnstone \& Johnston, 2005), mental and physical health (McMillan \& O'Driscoll, 2004), and work-family conflict (Bakker, Demerouti, \& Burke, 2009). However, the verity of these relationships is not easily estimated due to discrepancies across studies with respect to the criterion variables used. Thus, it is difficult to differentiate between true correlations and random error (c.f. Aziz \& Zickar, 2006; Burke \& Fiksenbaum, 2009; Schaufeli, Taris, \& van Rhenen, 2008).

A more prominent issue is the lack of consistency regarding the operationalization of workaholism across studies. For example, when utilizing the Work Addiction Risk Test, Schaufeli and colleagues (2008) renamed the "need for control" factor to "working excessively."Similarly, when utilizing the Workaholism Battery, Burke and Fiksenbaum (2009) renamed the "work enjoyment" factor to "passion and drive to addiction."Subsequently, an overabundance of measures purportedly measure workaholism but utilize different operational definitions. Thus again, it is difficult to ascertain the current state of workaholism and determine whether it has consistent relationships with other variables. Hence, the primary purpose of the present study is to clarify the current state of the construct of workaholism, specifically elucidating its relationship with some of the more common aspects of work behaviors and outcomes. Clarification of the correlates of workaholism will provide a step forward in developing a commonly agreed-upon definition of this form of addiction. Additionally, this study seeks to determine which, if any, measure of workaholism constitute a superior predictor of the work related outcomes typically examined within this literature base.

\subsection{Definitions of Workaholism}

The original conceptualization of a workaholic is "a person whose need for work has become so excessive that it creates noticeable disturbance or interference with his bodily health, personal happiness, and interpersonal relations, and with his smooth social functioning" (Oates, 1971). For over a decade after Oates' earliest description, the definition of workaholism did not evolve substantially. Nagy and Davis (1985) later redefined workaholism as "total devotion to an occupation or cause" (p. 1) and two years later, Booth-Kewley and Friedman (1987) utilized a simpler definition of a workaholic as a hurried, impatient individual. Similarly, Spruell (1987) additionally defined a workaholic simply as someone who works long hours regardless of the productivity engendered by the time spent. Although Spruell noted that endless hours of work are usually a manifestation of assorted motivators and result in different personal effects, she did not elaborate with regard to what those motivators and effects could be.

More recently, as the study of workaholism has progressed, the definition has evolved to include specific types of workaholics. Spence and Robbins (1992) presented a two-factor approach to workaholism, categorizing workaholics as either work enthusiasts or non-enthusiastic workaholics. By their definition, work enthusiasts are individuals who are very involved in their work and thoroughly enjoy it, but are not particularly driven or compelled to work. For example, someone who would be considered a work enthusiast would work many long hours every week because they genuinely enjoy their work, not because they have an insatiable need to work. Thus, these individuals seemingly have no negative mental or physical health consequences due to their workaholic nature, but perhaps may be emotionally struggling with deteriorating social relationships outside of work. In contrast, non-enthusiastic workaholics, or customary workaholics, are those who are highly involved in their work and lack enjoyment, yet feel driven to work. For example, a non-enthusiastic workaholic would be someone that works many long hours every week because they feel compelled to do so, not because they take pleasure in their work. Thus, these individuals may display more mental and physical strain than work enthusiasts, and also will likely experience unsatisfactory social relationships with family and friends.

Scott, Moore, and Miceli (1997) criticized Spence and Robbins' definition, contending that a definition of workaholism should involve more stable behavioral patterns. Specifically, they distinguished among three types of workaholics: compulsive-dependent workaholics, perfectionist workaholics, and achievement-oriented workaholics. According to Scott and colleagues, a compulsive dependent workaholic is an individual who works more than they intend to and, although they realize they are overworking themselves, they cannot physically and mentally abstain from working excessively. Thus, these types of workaholics are like many other addicts of different persuasions in that they recognize their addictive behavior and the harm it is causing, yet are unable to overcome the addiction of their own will. Perfectionist workaholics are similar to compulsive dependent workaholics in that they also show signs of obsessive compulsive personality disorder; however, perfectionist workaholics experience an overbearing need for control and are very meticulous. These individuals find it very 
difficult to share their work with team members and are compelled to be scrupulous over trivial details. Such behaviors can lead to discord with coworkers and inefficient use of time at work. Finally, achievement-oriented workaholics are described as competitive personalities who intensely desire success and a strong career identity. These individuals are driven to work excessively in order to achieve the goals they have established for themselves. It is likely that these individuals will not only physically and mentally exhaust themselves, but will probably also annihilate their relationships with their coworkers, friends, and family due to their insatiable competitive nature.

Robinson (2000) suggested a novel typology of workaholics that included relentless workaholics, bulimic workaholics, attention deficit workaholics, and savoring workaholics. He described relentless workaholics as the stereotypical workaholics who are high in both work initiation and work completion. These workaholics are probably most comparable to the achievement-oriented workaholics mentioned previously. They frequently invest long hours on the job and exceed what is asked of them due to an innate drive to work. Whereas relentless workaholics work compulsively and constantly, bulimic workaholics work more sporadically. Additionally, bulimic workaholics are known to be low in work initiation but high in work completion. These workaholics are unlikely to seek out work, but when presented with a new project, they are prone to adamantly work on it until it is completed. Their determination to finish their work tasks often leaves them mentally and physically exhausted, which is probably the cause of their low likelihood to initiate work. In contrast, attention deficit workaholics are high in work initiation but low in work completion because they are adrenaline-seeking and readily lose interest in work tasks. These individuals are addicted to the surge of energy and excitement engendered by new projects; thus, they may accumulate many different projects at once and ultimately experience burnout before any of the projects are completed. Finally, savoring workaholics are low in both work initiation and work completion; they are typically perfectionists who are so detail-oriented that they often miss deadlines. These individuals are prone to obsessive compulsive disorder and may find it difficult to work in teams as they need tasks to be completed according to their specific guidelines and standards.

Although these operational definitions have progressed from a simple description of workaholism as a compulsion to work to a more complex explanation of the different manifestations of workaholism, little empirical effort has specifically sought to identify the psychological, social, and physical effects of workaholism as an addiction. Alcoholism is known to have physical side effects such as liver failure and heart problems, along with psychological side effects such as depression and violent behavior. Unlike alcoholism and many other known addictions, workaholism has no openly agreed-upon physical, emotional, or mental effects. Therefore, this meta-analysis seeks to combine and analyze data from prior research measuring workaholism in an effort to increase our understanding of the overall impact of numerous operationalizations of workaholism.

\subsection{Measures of Workaholism}

There are numerous measures of workaholism including Clark's (1993) Schedule for Non adaptive and Adaptive Personality-Workaholism (SNAP-Work), Robinson and Carroll's (1999) Children of Workaholic Parents Screening Test (CWST), and Senholzi's (2008) Work Attitudes and Behaviors Inventory (WABI). However, of all of the workaholism measures, the two that have received the most empirical attention, and are subsequently the focus of this meta-analysis, are Spence and Robbins' (1992) Workaholism Battery (WorkBat) and Robinson's (1999) Work Addiction Risk Test (WART).

The WorkBat (1992) operationalizes workaholism as being comprised of three factors including (1) work enjoyment, (2) work involvement, and (3) drive to work. Specifically:

Work enjoyment is a measure of how much an individual likes doing his or her work, work involvement is an evaluation of how invested an individual is in his or her work, and drive to work is a measure of an individual's compulsion-like motivation to work. (p. 162)

The WorkBat is a self-report questionnaire consisting of 25 items divided between the three factors; work involvement (eight items), drive to work (seven items), and work enjoyment (10 items). All of the items utilize a five-point Likert scale ranging from 1 (disagree) to 5 (agree). Work enjoyment items are reverse-scored, after which high scores on all three factors are considered to be indicative of workaholism. Overall, the WorkBat has been used in approximately 482 studies, with each examining either individual factor scores or the aggregated score in relation to workaholism.

Robinson's (1999) Work Addiction Risk Test (WART) is growing in popularity as a measure of workaholism (c.f. Brady, Vodanovich, \& Rotunda, 2008; Brough, O'Driscoll, Kalliath, Cooper, \& Poelmans, 2009; Chamberlin \& Zhang, 2009). The WART operationalizes workaholism as a five-factor model including (1) 
compulsive tendencies, (2) control, (3) impaired communication/self-absorption, (4) inability to delegate, and (5) self-worth. Specifically:

Compulsive tendencies are characterized by one's need to hurry, stay busy, multitask, overly commit, feelings of guilt if not working, working long hours, placing self-imposed deadlines for oneself, difficulty relaxing, and lack of time spent socializing. Control is defined as a need for perfectionism that causes impatience, irritation, and anger towards others and oneself when work is not suitable to the workaholic's standards. Impaired communication and self-absorption is identified by lack of attentiveness to what others have to say, jumping into tasks before completing necessary prior steps, making decisions without factual support, and lack of interest in relationships with others and the milestones in their lives. Inability to delegate is the unwillingness to entrust others with work responsibilities and failure to ask others for help when it is needed. And finally, self-worth is described as feeling guilty when not working and being unforgiving towards one's minor mistakes and setbacks. (p. 202)

The WART is composed of 25 statements which participants are asked to rate on a scale of 1 (never true) to 4 (always true). Individuals scoring between 25 and 54 are usually considered not to be addicted to work, those between 55 and 69 are mildly work addicted, and those with scores of 70 to 100 are considered to be highly addicted. Overall, the WART has been used in approximately 138 studies that have examined individual factor scores and the aggregated score in relation to workaholism.

\subsection{Current State of Workaholism}

Despite the various conceptualizations of workaholism, consensus exists with regard to several expected outcomes. The majority of workaholism research hypothesized that one of the leading concerns of the disorder is its negative effect on one's personal relationships and social life (Bonebright \& Clay, 2000; Burke, 2000; Robinson \& Post, 1997). Research shows that workaholics' ratings of their condition are typically less severe than those provided by their significant others, and workaholics are more likely to experience greater disturbances in social relationships than non-workaholics (McMillan, O'Driscoll, \& Brady, 2004). Ironically, as the quality of social relationships decreases, the onset of workaholism is usually hypothesized to be propelled by encouragement and praise from co-workers and supervisors (Johnstone \& Johnston, 2005; Liang \& Chu, 2009; Smith, 2007).Support may come in the form of positive work evaluations and feedback (Piotrowski \& Vodanovich, 2006), competitive peers ( $\mathrm{Ng}$ et al., 2007), and workaholic supervisors setting high standards ( $\mathrm{Ng}$ et al., 2007).

Another common finding is that workaholism is correlated with long working hours. There is a general consensus among researchers that the longer the period of time one works beyond that which is necessary for their job, the more likely he or she is to become a workaholic (Burke \& Fiksenbaum, 2009; Burke et al., 2008; Feeney \& Bozeman, 2009; Robinson, Flowers, \& Ng, 2006; Snir \& Zohar, 2008;).These longer hours are usually not hypothesized to be motivated by monetary gain. Although income is just as compelling an incentive for workaholics as for non-workaholics, it has not been linked with the drive behind the disorder (Burke, 2004; Srivastava, Locke, \& Bartol, 2001).

Workaholism has also been purported to be related to burnout and negative feelings about work and life. Workaholism-induced burnout has been shown to be related to negative emotions due to high levels of stress, as well as more physical health symptoms (Burke, Richardsen, \& Mortinussen, 2004). Taris, Beckers, Verhoeven, Geurts, Kompier, and van der Linden (2006) hypothesized that work exhaustion and work-life interference caused by workaholism will result in negative feelings about oneself and life in general. Schaufeli and colleagues (2008) investigated the relationship between workaholism and burnout as a product of job demands. Schaufeli and colleagues (2009) also researched burnout as a result of work-life conflict due to workaholism.

\subsection{The Present Study}

Aside from the few commonalities discussed in the previous section, a lack of clarity remains regarding the consistent and specific relations workaholism has with one's personal life and overall wellbeing. This meta-analysis seeks to better understand the correlates of workaholism based on findings from previous research. Specifically, this study aims to identify the most common correlates of workaholism with hopes to develop a universally agreed-upon construct for the disorder. As previously noted, various definitions of workaholism exist that focus upon differing aspects of this form of addiction. Combining and analyzing the data from prior workaholism research will serve to increase our understanding of the overall impact of the numerous operationalizations of workaholism. Moreover, clarifying the construct of workaholism through its relationships 
with its correlates will help to illuminate the implications workaholism has on one's life, which will provide a step forward in its prognosis and prevention.

\section{Methods}

\subsection{Literature Search}

Articles were collected through an Internet search using the PsycINFO database (American Psychological Association, 1887-2009). No date range was set in order to ensure the most comprehensive analysis of workaholism measures. Keywords used in the search were workaholism, work addiction risk test, WART, workaholism battery, WorkBat, and workaholism measures. In addition, articles were located by conducting a reverse citation search for the Robinson (1999) article presenting the development of the WART and the Spence and Robbins (1992) article presenting the WorkBat. As previously noted, the WART and the WorkBat measures served as focal points due to their prominence within the study of workaholism.

\subsection{Inclusion Criteria}

Once the initial list of studies was created using the results of the literature search, several inclusion criteria were applied. First, only peer-reviewed articles, not student dissertations, were included in the meta-analysis. The use of only peer-reviewed articles ensured that only studies utilizing quality research designs were included. Next, of the foreign studies, only those that provided an English translation were considered for analysis due to limitations regarding the researcher's fluency in languages other than English. Lastly, in order to be included in the final set of articles for the meta-analysis, each study must have reported (1) correlations between the predictor (i.e., the WART or WorkBat) and criterion variables, and (2) the sample size used, as such statistical data is necessary to calculate the mean correlation of workaholism with the criterion variables and the $95 \%$ confidence intervals about those means. Overall, 44 studies were included in the meta-analysis.

\subsection{Data Coding}

Data cited in the included studies were coded according to specific rules developed to maintain inter-rater reliability. Three raters coded the studies independently and the data were subsequently compared for consistency among the raters. The identification coding for each study consisted of the initials of the rater, the date of the coding, a citation for the article, the date of publication, and a unique article identification number that was assigned to each article prior to coding. As some articles included more than one study, a unique number corresponding to each individual study within an article was also recorded, in the order in which the studies were reported within the article. For example, if the first article included two studies, the article identification number was 1, and the study identification numberswere 1 and 2 for the first and second study, respectively. Each predictor-criterion correlation reported within every study was also recorded.

The predictor codes (i.e., workaholism) included the measure name, the dimension name, and the type of measure studied (behavioral, self-report, supervisor rating, or other type of measure). If reported, the predictors' internal consistency, test-retest reliability, and inter-rater reliability were also recorded. The same coding scheme was applied to the criterion variables, and additionally included the general category of the criterion studied.

The criterion variables were placed into general categories by three raters individually categorizing each criterion and then cross-referencing the individual categorizations for inter-rater reliability. This process resulted in a final list of 28 general criterion categories with 95\% agreement among all three raters (see Table 1).

To test for moderators and assist with the analysis of the predictor-criterion correlations, demographic data of the samples were coded. Sample size, form of sampling conducted (online, in person, or via mail), participants' occupation (student, blue collar/manual labor, white collar/office position, upper level management, professional/doctoral, or other job type), and the country from which the sample was selected were all recorded. If provided by the studies, the percentage of each ethnicity and gender represented in the samples was noted, along with the average age, salary, and hours worked per week with their corresponding standard deviations. Finally, the overall quality of the studies was coded subjectively by listing any characteristics of the study that could potentially jeopardize the overall integrity of the analysis. After coding all of the above for each study, the raters indicated whether or not the study should be included in the final analysis. 
Table 1. Criterion measure categorizations

\begin{tabular}{|c|c|c|}
\hline Achievement Motivation & Job Involvement & Negative Non-performance work Behaviors \\
\hline Achievement Needs & Absorption & Depersonalization \\
\hline Drive & Involvement & Impaired Communication \\
\hline Intrinsic Job Motivation & Job Involvement & Impaired Social Functioning \\
\hline Perception of Feeling Driven & Parsimony & Intent to Quit \\
\hline Perseverance & Perception of Work Involvement & Interpersonal Deviance \\
\hline \multirow[t]{2}{*}{ Type A Behavior Subscale } & Superego & Low accomplishment \\
\hline & Thinking about work & Negative Reactions \\
\hline Agreeableness & Work Centrality & Non-delegation \\
\hline Agreeableness & Work Involvement & Organizational Deviance \\
\hline \multirow[t]{2}{*}{ Trust others } & & Reduced Medical Accomplishment \\
\hline & Job Stress & \\
\hline Commitment and Cohesion & Communication Scale & Perceived Control \\
\hline Commitment & Emotional Demands & Job Control \\
\hline Co-worker Cohesion & Job Stress & Locus of Control \\
\hline Co-worker Support & Leadership Scale & Perceived Job Control \\
\hline Dedication & Mental Demands & \\
\hline Organizational Commitment & Promotion Scale & Perceived Job Demands \\
\hline \multirow[t]{2}{*}{ Supervisor Support } & Psychological Job Demands & Extra Hours Worked \\
\hline & Role Ambiguity & Organizational Demands \\
\hline Conscientiousness & Role Conflict & Overwork \\
\hline Conscientiousness & Work Pressure & Supervisors work 50 -hour+ weeks \\
\hline Orderliness & Work Stress & Peers work 50 -hour+ weeks \\
\hline \multirow[t]{2}{*}{ Self-Monit oring } & Workload Scale & Perceived Job Demands \\
\hline & Work-related Stress Complaints & Work Overload \\
\hline Extraversion & & Work Overload-Quality \\
\hline Extraversion & Mental Health & Work Overload-Quantity \\
\hline \multirow[t]{2}{*}{ Expressive Orientation } & Anxiety & \\
\hline & Depression & Perfectionism \\
\hline Flexibility & Distress & Other-Oriented Perfectionism \\
\hline Obsessive-Compulsive & Emotional Exhaustion & Perfectionism \\
\hline Obstinacy & Emotional Health & Self-Oriented Perfectionism \\
\hline Openness to new experiences & Mental Health & Socially Prescribed Perfectionism \\
\hline Rigidity & Neuroticism & \\
\hline \multirow[t]{2}{*}{ Tolerance of Ambiguity } & Psychosomatic Complaints & Physical Health \\
\hline & & Gastrointestinal Scale \\
\hline Job Characteristic & Need for Affiliation & Heart Attacks \\
\hline Being at a work-related location & "All in this together" & Musculoskeletal Scale \\
\hline Being with people from the work domain & Affiliation Needs & Perceived Health \\
\hline Employment Sector & Value in all & Physical Health \\
\hline Labor force sampling year & & Pseudoneurology Scale \\
\hline Managerial Status & Need for Power & Psychosomatic Symptoms \\
\hline Non-profit organization & Control of Others & \\
\hline Number of hours contract & Dominance Needs & \\
\hline \multicolumn{3}{|l|}{ Occupation Type } \\
\hline Organization Size & Negative Affect Towards Non-work & \\
\hline Organizational Level & More likely to respond to mistakes & \\
\hline \multicolumn{3}{|l|}{ Organizational Values } \\
\hline \multicolumn{3}{|l|}{ Calculated risks are encouraged } \\
\hline \multicolumn{3}{|l|}{ Work Itself } \\
\hline Work Situation & & \\
\hline
\end{tabular}


Table 1. (cont.)

Positive Affect Towards Non-work

Average positive affect

Community Satisfaction

Emotional Satisfaction

Enjoyment

Family Satisfaction

Happiness

Life Satisfaction

Mean of Five Life Satisfaction Measures

Physical Health Satisfaction

Physical Satisfaction

Positive

Positive Feeling

Relationship satisfaction

Self-Esteem

Self-Worth

Positive Affect Towards Work

Career Satisfaction

Enjoyment Conducting Psychotherapy

Fun at Work

Job Satisfaction

Preferring work-related activity

Self and Co-worker Perception of Joy in Work

Positive Non-performance Work Behaviors

Challenging Organizational Deviance

Delegation

Flow

Innovative Organizational Deviance

Interpersonal Constructive Deviance

Interpersonal Relations

Self-efficacy
Beliefs and Fears
Composite Measure of Beliefs and Fears
General self-efficacy
Professional Efficacy

Work Effort

Average of Perceived Time and Effort Score Financial Needs

Hours worked per week Gender

Perceived Effort Marital Status

Perceived Time Parental Status

Performing work-related activity Personal Demographics

Time on Job

Vigor

Work-life Balance

Balance

Balance and Imbalance Values

Balance of Rewards

Balance Values

Life separate from work

Imbalance

Imbalance Values

Inter-role Conflict

Nights Away from home per month

Social support from partner

Strain-based Interference

Time-based Interference

Work-family conflict

Work-Life Balance

Work-Life Conflict

Work-Nonwork Conflict

Purpose in Life

\author{
Uncategorized \\ Age \\ Antecedents \\ Changed Job Since Graduation \\ Economic Orientation \\ Education Level \\ Experience
}

Physical Attraction

Relationship Status

Organization has a narrow view

Years Employer

Years Job

Young children present

Professional Success

Affluence

Annual Income

Career Prospects

Future Career Prospects

Personal Accomplishment

Promotions

Salary

Salary Increase

Tenure

\section{Results}

\subsection{Work Addiction Risk Test}

Table 2 presents a summary of the average correlations between the dimensions of the Work Addiction Risk Test (WART) and the criterion categories of possible workaholism correlates. The effect sizes of the correlation coefficients were rationalized using Cohen's (1988) suggestion that a large effect size is greater than or equal to .5; a moderate effect is between .5 and .3 ; and a correlation between .3 and .1 is small.

Table 2 also presents the $95 \%$ confidence intervals about the mean correlation coefficients using the Fisher $r$-to- $z$ transformation and the sample population, $n$. As observed within Table 2, several mean correlation coefficients emerged for which the confidence interval included zero; thus, these scores are not significantly different from zero at the $95 \%$ confidence level. 


\subsubsection{Aggregated}

Overall, scores on the aggregated WART displayed no significant correlation with job stress, perceived control, positive affect towards non-work, and self-efficacy. However, scores on the aggregated WART did demonstrate a weak but significant relationship with demographic, job characteristics, negative affect towards non-work, and work effort. Furthermore, scores on the aggregated WART displayed moderate significant correlations with negative affect towards work, perceived job demands, and work-life balance. Moreover, the aggregated WART scores yielded a highly significant correlation with mental health, suggesting that workaholism, as measured by the aggregated WART, is significantly related to mental health. However, it should be noted that this correlation is based on a relatively small sample size. Although the effect sizes of the correlations between the aggregated WART and negative affect towards work, perceived job demands, and work-life balance were not as large as the effect size for mental health, the strength of the correlations with these other criterion measures suggests that they are also related to workaholism. Thus, the relationship between the aggregated WART and these correlates is worthy of consideration.

\subsubsection{Compulsive Tendencies}

Overall, scores on the Compulsive Tendencies dimension of the WART displayed no significant correlation with demographics or perceived control. However, scores on the Compulsive Tendencies dimension did demonstrate weak significant correlations with job stress, negative affect towards non-work, positive affect towards non-work, professional success, and work effort. Scores on the Compulsive Tendencies dimension evidenced moderate correlations with negative affect towards work and negative non-performance work behaviors. Strong correlations emerged between scores on the Compulsive Tendencies dimension and need for power, perceived job demands, and work-life balance. Hence, need for power, perceived job demands, and work-life balance all displayed strong relationships with workaholism as measured by the Compulsive Tendencies dimension of the WART. Although the correlations between the scores on the Compulsive Tendencies dimension and negative affect towards work and negative non-performance work behaviors were less robust than the previously stated correlations, their relationship with workaholism should nevertheless be noted.

\subsubsection{Control}

The Control dimension of the WART demonstrated no significant correlations with mental health or self-efficacy. However, scores on the Control dimension did exhibit weak, yet significant, correlations with commitment and cohesion, negative affect towards work, negative non-performance work behaviors, perceived control, positive affect towards work, and work effort. Furthermore, scores on the Control dimension displayed moderate significant correlations with job involvement, negative affect towards non-work, perceived job demands, and positive affect towards non-work. Although these correlations are only moderate in strength, they represent an attention-worthy significant relationship with workaholism through the Control dimension of the WART. In addition, a strong significant correlation emerged between scores on the Control dimension and job stress, indicating that level of job stress and a workaholic's need for control are highly related.

\subsubsection{Delegation}

Scores on the Delegation dimension of the WART demonstrated no significant correlations with perceived control, positive affect towards non-work, or work effort. However, weak significant correlations were noted between scores on the Delegation dimension and both negative affect towards non-work and physical health. Scores on the Delegation dimension did not yield moderate or strong significant correlations with any of the criterion variables.

\subsubsection{Impaired Communication}

Scores on the Impaired Communication dimension of the WART did not evidence significant correlations with perceived control or work effort. However, scores on the Impaired Communication dimension did demonstrate moderate significant correlations with negative affect towards non-work and positive affect towards non-work. Although no strong significant correlations emerged between the Impaired Communication dimension scores and the criterion measures, the moderate correlations stated above indicate that these criteria are significantly related to workaholism as measured by the WART. 
Table 2. Work addiction risk test

\begin{tabular}{|c|c|c|c|c|c|c|c|c|c|c|c|c|c|c|c|c|c|c|c|c|c|c|c|c|c|c|c|c|c|c|}
\hline & \multicolumn{5}{|c|}{ Aggregated } & \multicolumn{5}{|c|}{ Compulsive Tendencies } & \multicolumn{5}{|c|}{ Control } & \multicolumn{5}{|c|}{ Delegation } & \multicolumn{5}{|c|}{ Impaired Communication } & \multicolumn{5}{|c|}{ Self Worth } \\
\hline & $\mathrm{n}$ & $\mathrm{k}$ & $\mathrm{r}$ & $\mathrm{L}$ & $\mathrm{U}$ & $\mathrm{n}$ & $\mathrm{k}$ & $\mathrm{r}$ & $\mathrm{L}$ & $\mathrm{U}$ & $\mathrm{n}$ & $\mathrm{k}$ & $\mathrm{r}$ & $\mathrm{L}$ & $\mathrm{U}$ & $\mathrm{n}$ & $\mathrm{k}$ & $\mathrm{r}$ & $\mathrm{L}$ & $\mathrm{U}$ & $\mathrm{n}$ & $\mathrm{k}$ & $\mathrm{r}$ & $\mathrm{L}$ & $\mathrm{U}$ & $\mathrm{n}$ & $\mathrm{k}$ & $\mathrm{r}$ & $\mathrm{L}$ & $\mathrm{U}$ \\
\hline \multicolumn{31}{|l|}{ Achievement Motivation } \\
\hline \multicolumn{31}{|l|}{ Agreeableness } \\
\hline Commitment and Cohesion & & & & & & & & & & & 2348 & 4 & .09 & .05 & .13 & & & & & & & & & & & & & & & \\
\hline \multicolumn{31}{|l|}{ Conscientiousness } \\
\hline Demographic & 464 & 4 & .11 & .02 & .20 & 862 & 6 & .07 & & .14 & & & & & & & & & & & & & & & & & & & & \\
\hline \multicolumn{31}{|l|}{ Extraversion } \\
\hline \multicolumn{31}{|l|}{ Flexibility } \\
\hline Job Characteristic & 464 & 4 & .17 & .08 & .26 & & & & & & & & & & & & & & & & & & & & & & & & & \\
\hline Job Involvement & & & & & & & & & & & 587 & 1 & .37 & .31 & .44 & & & & & & & & & & & & & & & \\
\hline Job Stress & 130 & 1 & .17 & & .34 & 130 & 1 & .20 & .03 & .37 & 587 & 1 & .58 & .53 & .64 & & & & & & & & & & & & & & & \\
\hline Mental Health & 102 & 1 & .67 & .55 & .77 & & & & & & 2348 & 4 & .04 & & .08 & & & & & & & & & & & & & & & \\
\hline \multicolumn{31}{|l|}{ Need for Affiliation } \\
\hline Need for Power & & & & & & 326 & 1 & .51 & .43 & .59 & & & & & & & & & & & & & & & & & & & & \\
\hline Negative Affect Towards Non-work & 1450 & 8 & .20 & .15 & .25 & 870 & 3 & .16 & .09 & .23 & 870 & 3 & .37 & .31 & .43 & 544 & 2 & .10 & .02 & .18 & 870 & 3 & .43 & .38 & .49 & 870 & 3 & .18 & .12 & .25 \\
\hline Negative Affect Towards Work & 464 & 4 & .33 & .25 & .41 & 663 & 5 & .37 & .31 & .43 & 1174 & 2 & .20 & .15 & .26 & & & & & & & & & & & & & & & \\
\hline Negative Non-performance work Behaviors & & & & & & 326 & 1 & .41 & .32 & .50 & 1500 & 3 & .19 & .14 & .24 & & & & & & & & & & & & & & & \\
\hline Perceived Control & 598 & 2 & .01 & -.07 & .09 & 272 & 1 & .09 & -.03 & .21 & 859 & 2 & .15 & .08 & .22 & 272 & 1 & .02 & -.10 & .14 & 272 & 1 & .12 & & .24 & 272 & 1 & $.04-$ & -.08 & .16 \\
\hline Perceived Job Demands & 232 & 2 & .32 & .20 & .43 & 431 & 3 & .50 & .43 & .57 & 587 & 1 & .43 & .37 & .50 & & & & & & & & & & & & & & & \\
\hline \multicolumn{31}{|l|}{ Perfectionism } \\
\hline Physical Health & & & & & & & & & & & & & & & & 733 & 1 & .10 & .03 & .17 & & & & & & & & & & \\
\hline Positive Affect Towards Non-work & 830 & 4 & .05 & -.02 & .12 & 1492 & 7 & .22 & .17 & .27 & 924 & 3 & .37 & .31 & .43 & 272 & 1 & .03 & -.09 & .15 & 924 & 3 & .38 & .33 & .43 & 598 & 2 & .20 & .12 & .28 \\
\hline Positive Affect Towards Work & & & & & & & & & & & 587 & 1 & .21 & .13 & .29 & & & & & & & & & & & & & & & \\
\hline \multicolumn{31}{|l|}{ Positive Non-performance Work Behaviors } \\
\hline Professional Success & & & & & & 398 & 2 & .16 & .06 & .26 & & & & & & & & & & & & & & & & & & & & \\
\hline Self-efficacy & 232 & 2 & .05 & -.08 & .18 & & & & & & 587 & 1 & .06 & -.02 & .14 & & & & & & & & & & & & & & & \\
\hline Work Effort & 272 & 1 & .18 & .06 & .29 & 272 & 1 & .23 & .11 & .34 & 859 & 2 & .12 & .05 & .19 & 272 & 1 & .09 & -.03 & .21 & 272 & 1 & .06 & -.06. & .18 & 272 & 1 & .13 & .01 & .25 \\
\hline Work-life Balance & 594 & 5 & .36 & .29 & .43 & 1001 & 6 & .56 & .52 & .60 & & & & & & & & & & & & & & & & & & & & \\
\hline
\end{tabular}

Note. $\mathrm{n}=$ total sample size; $\mathrm{k}=$ number of studies; $\mathrm{r}=$ average weighted correlation; $\mathrm{L}=$ lower limit of $95 \%$ confidence interval; $\mathrm{U}=$ upper limit of $95 \%$ confidence interval.

\subsubsection{Self-Worth}

No significant correlations resulted between scores on the Self-Worth dimension of the WART and perceived control. However, scores on the Self-Worth dimension did demonstrate weak significant correlations with negative affect towards non-work, positive affect towards non-work, and work effort. Self-Worth dimension scores did not display moderate or strong significant correlations with any of the workaholism criteria studied.

\subsubsection{Summary}

The absence of moderate or strong significant relationships between the WART dimensions of Self-Worth and Delegation with any of the criterion measures indicates that they may be measuring other aspects of workaholism that have yet to be studied, or that these dimensions may not be viable aspects of workaholism. The Compulsive Tendencies and the Control dimensions appear to account for the largest effects of workaholism according to the criteria employed in this meta-analysis. None of the criterion categories displayed a strong relationship with all five dimensions of the WART. The aggregated WART only had a strong relationship with the mental health criterion, but this criterion's relationship with the individual dimensions has not yet been examined (except for an insignificant correlation with the Control dimension).

\subsection{Workaholism Battery}

As with the previous analyses, Table 3 presents a summary of the average correlations linking the dimensions of the Workaholism Battery (WorkBat) to criterion categories of possible workaholism correlates. Additionally, Table 3 also presents the $95 \%$ confidence intervals about the mean correlation coefficients, using the Fisher $r$-to- $z$ transformation and the sample population, $n$, with several mean correlation coefficients not being significantly different from zero at the $95 \%$ confidence level.

\subsubsection{Aggregated}

Overall, scores on the aggregated WorkBat dimension displayed weak significant correlations with perceived job demands and positive affect towards non-work. The aggregated WorkBat dimension scores also demonstrated moderate significant correlations with negative non-performance work behaviors, perfectionism, physical health, and positive affect towards work. Furthermore, the aggregated WorkBat cores yielded strong significant correlations with job characteristics, job involvement, job stress, mental health, professional success, and work effort. These moderate and strong correlations indicate that workaholism, as measured by the WorkBat, is significantly related to these criteria. In light of these correlations and the WorkBat's definition of workaholism, 
it appears that the characteristics of one's job, involvement with this job, level of job stress, mental health status, and level of professional success may offer a viable method of identifying workaholic tendencies.

\subsubsection{Drive}

Scores on the Drive dimension of the WorkBat did not yield any significant correlations with conscientiousness, extraversion, professional success, or relationship status. However, Drive dimension scores did demonstrate weak significant correlations with agreeableness, commitment and cohesion, demographics, flexibility, job characteristics, job involvement, mental health, negative affect towards non-work, negative affect towards work, negative non-performance work behaviors, perceived control, physical health, positive affect towards non-work, positive affect towards work, positive non-performance work behaviors, self-efficacy, and work effort. Moreover, Drive dimension scores exhibited moderate correlations with achievement motivation, job stress, perceived job demands, perfectionism, and work-life balance. These moderate correlations indicate that workaholism, as defined through this dimension, is significantly related to one's motivation for achievement, level of job stress, job demands, need for perfectionism, and ability to balance work and life activities.

\subsubsection{Work Enjoyment}

Scores on the Work Enjoyment dimension of the WorkBat were not significantly correlated with conscientiousness. However, Work Enjoyment dimension scores demonstrated weak significant correlations with achievement motivation, agreeableness, demographics, extraversion, flexibility, job characteristics, job stress, mental health, need for affiliation, negative affect towards non-work, negative non-performance work behaviors, perceived control, perceived job demands, perfectionism, physical health, positive affect towards non-work, positive non-performance work behaviors, professional success, relationship status, self-efficacy, work effort, and work-life balance. Furthermore, Work Enjoyment dimension scores yielded moderate correlations with commitment and cohesion, job involvement, negative affect towards work, and positive affect towards work, suggesting that they are significantly related to workaholism as measured by the Work Enjoyment dimension of the WorkBat and should be acknowledged as integral to the disorder.

Table 3. Woekaholism battery

\begin{tabular}{|c|c|c|c|c|c|c|c|c|c|c|c|c|c|c|c|c|c|c|c|c|}
\hline & \multicolumn{5}{|c|}{ Aggregated } & \multicolumn{5}{|c|}{ Drive } & \multicolumn{5}{|c|}{ Work Enjoyment } & \multicolumn{5}{|c|}{ Work Involvment } \\
\hline & $\mathrm{n}$ & $\mathrm{k}$ & $\mathrm{r}$ & $\mathrm{L}$ & $\mathrm{U}$ & $\mathrm{n}$ & $\mathrm{k}$ & $\mathrm{r}$ & $\mathrm{L}$ & $\mathrm{U}$ & $\mathrm{n}$ & $\mathrm{k}$ & $\mathrm{r}$ & $\mathrm{L}$ & $\mathrm{U}$ & $\mathrm{n}$ & $\mathrm{k}$ & $\mathrm{r}$ & $\mathrm{L}$ & $\mathrm{U}$ \\
\hline Achievement motivation & & & & & & 562 & 3 & .34 & .27 & .42 & 495 & 2 & .26 & .18 & .34 & 1060 & 2 & .25 & .20 & .31 \\
\hline Agreeableness & & & & & & 496 & 1 & .14 & .05 & .23 & 793 & 2 & .23 & .16 & .29 & 46 & 1 & .04 & -.26 & .33 \\
\hline Commitment and cohesion & & & & & & 2885 & 9 & .11 & .07 & .15 & 748 & 6 & .34 & .28 & .41 & & & & & \\
\hline Conscientiousness & & & & & & 496 & 1 & .02 & -.07 & .11 & 496 & 1 & .07 & -.02 & .16 & 496 & 1 & .02 & -.07 & .11 \\
\hline Extraversion & & & & & & 496 & 1 & .04 & -.05 & .13 & 496 & 1 & .21 & .12 & .29 & 496 & 1 & .00 & -.09 & .09 \\
\hline Flexibility & & & & & & 816 & 2 & .29 & .23 & .36 & 816 & 2 & .17 & .10 & .24 & 496 & 1 & .08 & -.01 & .17 \\
\hline Job characteristic & 171 & 1 & .58 & .47 & .67 & 4042 & 11 & .12 & .09 & .15 & 5154 & 16 & .19 & .17 & .22 & 4298 & 12 & .07 & .04 & .10 \\
\hline Job involvement & 556 & 2 & .66 & .62 & .71 & 2894 & 12 & .27 & .24 & .31 & 3194 & 13 & .40 & .01 & .07 & 1239 & 6 & .27 & .22 & .32 \\
\hline Job stress & 387 & 1 & .54 & .46 & .61 & 3206 & 12 & .37 & .34 & .40 & 3219 & 12 & .24 & .21 & .28 & 704 & 2 & .07 & & .14 \\
\hline Mental health & 171 & 1 & .58 & .47 & 67 & 3545 & 7 & .28 & .25 & .31 & 2255 & 5 & .21 & .17 & .25 & 1026 & 2 & .04 & -.02 & .10 \\
\hline Need for affiliation & & & & & & & & & & & 594 & 2 & .20 & .12 & .28 & & & & & \\
\hline \multicolumn{21}{|l|}{ Need for power } \\
\hline Negative affect towards non-work & & & & & & 464 & 4 & .21 & .12 & .29 & 675 & 5 & .11 & .03 & .19 & 464 & 4 & .28 & .20 & .37 \\
\hline Negative affect towards work & & & & & & 1644 & 4 & .29 & .25 & .34 & 1388 & 6 & .34 & .29 & .39 & & & & & \\
\hline Negative non-performance work behaviors & 1120 & 4 & .42 & .38 & .47 & 3078 & 8 & .20 & .17 & .24 & 3413 & 10 & .17 & .14 & .21 & 1344 & 4 & .08 & .03 & .13 \\
\hline Perceived control & & & & & & 587 & 1 & .18 & .10 & .26 & 199 & 1 & .23 & .09 & .36 & & & & & \\
\hline Perceived job demands & 389 & 1 & .30 & .21 & .39 & 7160 & 12 & .35 & .33 & .38 & 7366 & 14 & .08 & .06 & .10 & & & & & \\
\hline Perfectionism & 387 & 1 & .46 & .38 & .54 & 1291 & 3 & .38 & .34 & .43 & 2706 & 7 & .28 & .25 & .32 & 590 & 2 & .14 & .06 & .22 \\
\hline Physical health & 557 & 2 & .46 & .39 & .53 & 1765 & 5 & .19 & .15 & .24 & 4052 & 10 & .22 & .19 & .25 & 1060 & 2 & .08 & .02 & .14 \\
\hline Positive affect towards non-work & 1905 & 5 & .26 & .22 & .31 & 3876 & 12 & .16 & .13 & .19 & 5497 & 17 & .16 & .13 & .19 & 3756 & 10 & .06 & .03 & .09 \\
\hline Positive affect towards work & 948 & 3 & .39 & .34 & .45 & 2375 & 7 & .12 & .08 & .16 & 4979 & 15 & .31 & .29 & .34 & 1468 & 5 & .10 & .05 & .15 \\
\hline Positive non-performance work behaviors & & & & & & 807 & 4 & .15 & .08 & .22 & 1018 & 5 & .13 & .07 & .19 & 807 & 4 & .12 & .05 & .19 \\
\hline Professional success & 171 & 1 & .50 & .38 & .61 & 1650 & 4 & .04 & -.01 & .09 & 1789 & 4 & .15 & .10 & .20 & 1590 & 3 & .04 & -.01 & .09 \\
\hline Self-efficacy & & & & & & 2438 & 6 & .24 & .21 & .28 & 1791 & 4 & .24 & .20 & .29 & 1556 & 3 & .02 & -.03 & .07 \\
\hline Work effort & 357 & 1 & .71 & .66 & .77 & 2812 & 8 & .25 & .22 & .29 & 3554 & 11 & .24 & .21 & .28 & 1669 & 6 & .22 & .18 & .27 \\
\hline Work-life balance & & & & & & 983 & 7 & .36 & .31 & .42 & 2607 & 13 & .13 & .09 & .17 & 1761 & 10 & .18 & .14 & .23 \\
\hline
\end{tabular}

Note. $\mathrm{n}=$ total sample size; $\mathrm{k}=$ number of studies; $\mathrm{r}=$ average weighted correlation; $\mathrm{L}=$ lower limit of $95 \%$ confidence interval; $\mathrm{U}=$ upper limit of $95 \%$ confidence interval. 


\subsubsection{Work Involvement}

Scores on the Work Involvement dimension of the WorkBat did not yield any significant correlations with agreeableness, conscientiousness, extraversion, flexibility, mental health, professional success, or self-efficacy. However, scores on the Work Involvement dimension did demonstrate weak significant correlations with achievement motivation, demographics, job characteristics, job involvement, negative affect towards non-work, negative non-performance work behaviors, perfectionism, physical health, positive affect towards non-work, positive affect towards work, positive non-performance work behaviors, relationship status, work effort, and work-life balance. No moderate or strong significant correlations emerged between scores on the Work Involvement dimension and any of the criterion variables.

\subsubsection{Summary}

Despite the absence of strong significant correlations between any of the criterion categories and the individual dimensions of the WorkBat, several strong relationships nevertheless emerged between the aggregated WorkBat and the criterion measures. This pattern of results indicates that drive to work, work involvement, and work enjoyment must be combined in order to successfully correlate the WorkBat's definition of workaholism with the criterion measures that have been shown to identify with the aggregated WorkBat. When analyzed individually, these three dimensions appear to lack the power necessary to correlate with any particular workaholism criteria.

\section{Discussion}

The Work Addiction Risk Test (WART) and the Workaholism Battery (WorkBat) are the two most prominent measures of workaholism, yet the results of this meta-analysis indicate that few meaningful relationships with the criteria of interest are shared by both measures. In fact, only a few moderate to strong relationships with criterion variables are shared within the dimensions of each measure. Such discrepancies between and within two measures that purport to evaluate the same condition indicate that the definition of workaholism warrants further clarification.

With respect to the WART, of the 28 workaholism criterion categories, only five (negative affect towards non-work, negative affect towards work, perceived job demands, positive affect towards non-work, and work-life balance) shared significant correlations with two or more WART dimensions. The Control and the Impaired Communication dimensions both displayed moderate correlations with negative affect towards non-work and positive affect towards non-work. None of the WorkBat dimensions displayed correlations greater than .3 with these two categories.

The aggregated WART and the Compulsive Tendencies dimension both evidenced moderate to strong relationships with negative affect towards work, perceived job demands (which also had a significant relationship with the Control dimension), and work-life balance. These workaholism criterion categories also demonstrated moderate relationships with a few of the WorkBat dimensions. Negative affect towards work shared a moderate relationship with the WorkBat's Work Enjoyment dimension. The Drive dimension displayed moderate relationships with both perceived job demands and work-life balance. Although these significant relationships indicate that both the WART and the WorkBat seek to assess a few of the same correlates of workaholism, they also highlight the absence of strong relationships between these measures' dimensions and the criterion variables. For example, while a strong relationship emerged between the aggregated WorkBat dimension and work effort, all of the individual WorkBat dimensions and all of the WART dimensions displayed very weak or non-significant relationships with work effort. In addition, the Compulsive Tendencies dimension of the WART demonstrated a strong relationship with need for power, yet none of the other dimensions of either measure have been researched in relation to need for power.

The lack of consistency in the relationships between these two workaholism measures and the criterion variables of interest underscores the need for a standardized definition of workaholism. Although the individual WorkBat dimensions evidenced few meaningful relationships with the criterion variables, the aggregated WorkBat was strongly correlated with job characteristics, job involvement, job stress, mental health, professional success, and work effort. In contrast, each of the WART dimensions displayed at most one strong relationship with various criterion variables. The few moderate effects shared among the WART dimensions appeared to focus upon workaholic correlates such as positive and negative affect towards work and non-work, perceived job demands, and work-life balance. These discrepancies in the criteria with which each measure evidenced a strong relationship suggest that these measures assess qualitatively different traits that fit their varying definitions of workaholism. The WART and the WorkBat appear to use two different working definitions of workaholism, which has resulted in the measurement of uniquely different aspects of the disorder. 
In order to achieve more consistent results across workaholism studies, it is critical for a universal definition to first be established. A potential premise for such a definition could be the few criterion categories across both the WART and WorkBat measures that have resulted in promising relationships between the measures' dimensions and the workaholism correlates. For example, the aggregated WART and the aggregated WorkBat both evidenced significant correlations with mental health $(r=.67$ and .58 , respectively). Similarly, the aggregated WART and the Control dimension of the WorkBat both displayed strong correlations with job stress $(r=.54$ and .58 , respectively).A proposed definition could examine these common relationships with workaholism correlates across workaholism measures and use this as the basis for a consistent characterization of workaholism.

As with any disease, condition, or disorder, the symptoms and their effects must first be determined in order to better understand its causes and treatment. Current research seems to have adopted a retrospective approach in that it has invented a condition, workaholism, and is now attempting to unearth symptoms that could possibly engender this condition. Workaholism should be treated no differently than any other medical condition in that the addictive behaviors must first be identified and agreed upon, and their influence on the lives of those affected must be examined before the causes of the addiction and the treatment of it may be determined. Presently, it has been well established that particular individuals are addicted to working in a way that negatively affects their psychological, physical, and social health. The current challenge for researchers is to identify and reach a consensus regarding what these psychological, physical, and social health issues are and how they manifest themselves in individuals as possible symptoms of workaholism. Only after the symptoms of the disorder are ascertained can researchers determine a single, coherent, and conclusive definition of workaholism for which they may develop measures to ease the process of making an accurate diagnosis.

\subsection{Limitations}

As with any research methodology, certain limitations and weaknesses pertained to this meta-analysis. Language barriers prevented the inclusion of international research that had not been transcribed into English. Also, only those studies that reported correlation coefficients and sample sizes were garnered in this meta-analysis, as those values were necessary in order to compare and analyze data across all studies. Furthermore, the demographics of the participants in the individual studies were collected but could not be used in the analysis due to the lack of consistency in the units of measurements across all studies. For example, some studies reported participants' job type by directly stating their occupation, whereas other studies classified occupations as 'blue collar' or 'white collar' without specifying the actual occupations. Variance in the method of providing demographics was too great to derive statistically meaningful results, and hence, was not included in the analysis. Other limitations included subjective coding of criterion measures into general categories. Although inter-rater reliability was confirmed, the categories were still subjectively determined for comparison purposes. Finally, as with all meta-analytical studies, the quality of the results is only as good as the original data from which they are drawn. Although precautions were taken by omitting studies that did not feature quality research designs, this too was a subjective task, and all such studies may not have been removed.

\subsection{Future Research}

Future research would benefit from focusing upon the personality traits and situational characteristics that influence the manifestation of problematic symptoms that may lead to work addiction. Rather than focus research upon one's own definition of workaholism and investigate criterion variables that fit this definition, it would be advantageous for researchers to first identify the specific behaviors that engender addictive work patterns and the way in which these addictive cycles influence individuals and the organizations for which they work. Only after examining the foundation of addictive work behaviors can a definition regarding the positive or negative effects of workaholism upon an individual's life and the organization employing them be meaningfully determined. It is imperative to the study of workaholism that a single collective definition is constructed in order to develop measures that can accurately and reliably identify the disorder. In an effort to develop a universally agreed-upon definition, researchers must first establish the ways in which individuals are physically, socially, and psychologically impacted by their excessive work habits. The condition of workaholism clearly exists, but future research must take a step back and first establish a foundation of symptoms and outcomes of the disorder before diagnostic measures, such as the WART and WorkBat, may be used to pursue the causes and treatment of workaholism.

\section{Conclusions}

The study of workaholism is still in its infancy and will require significant collaboration among researchers and modifications of current definitions in order to achieve a coherent conceptual description. Currently the WART 
and the WorkBat constitute two reliable measures of workaholism, but their practical applicability and empirical utility will be hindered until an agreed-upon definition of workaholism is attained. As evidenced by the results, each of these measures correlate with fundamentally different workaholism components, suggesting the need for a consistent definition of workaholism. This meta-analysis has undertaken the first step in this process by identifying the shortcomings of current workaholism measures and addressing focal needs for future research.

\section{References}

American Psychological Association. (1887-2009). PsycINFO [Online]. Washington, D.C.: Author [Producer]. NC Live [Distributor].

Andreassen, C., Ursin, H., \& Eriksen, H. (2007). The relationship between strong motivation to work, 'workaholism', and health. Psychology \& Health, 22, 615-629. http://dx.doi.org/10.1080/14768320600941814

Aziz, S., \& Zickar, M. (2006). A cluster analysis investigation of workaholism as a syndrome. Journal of Occupational Health Psychology, 11, 52-62. http://dx.doi.org/10.1037/1076-8998.11.1.52

Bakker, A., Demerouti, E., \& Burke, R. (2009). Workaholism and relationship quality: A spillover-crossover perspective. Journal of Occupational Health Psychology, 14, 23-33. http://dx.doi.org/10.1037/a0013290

Bonebright, C., \& Clay, D. (2000). The relationship of workaholism with work-life conflict, Life satisfaction, and purpose in life. Journal of Counseling Psychology, 47, 469. Retrieved from Academic Search Premier database. http://dx.doi.org/10.1037/0022-0167.47.4.469

Booth-Kewley, S., \& Friedman, H. (1987). Psychological predictors of heart disease: A quantitative review. Psychological Bulletin, 101, 343-362. http://dx.doi.org/10.1037/0033-2909.101.3.343

Brady, B., Vodanovich, S., \& Rotunda, $R$. (2008). The impact of workaholism on work-family conflict, job satisfaction, and perception of leisure activities. Psychologist-Manager Journal, 11, 241-263. http://dx.doi.org/10.1080/10887150802371781

Brough, P., O'Driscoll, M., Kalliath, T., Cooper, C., \& Poelmans, S. (2009). Workplace psychological health: Current research and practice. Northampton, MA US: Edward Elgar Publishing.

Buelens, M., \& Poelmans, S. (2004). Enriching the Spence and Robbins' typology of workaholism: Demographic, motivational and organizational correlates. Journal of Organizational Change Management, 17, 440-458. http://dx.doi.org/10.1108/09534810410554470

Burke, R. (1999a). It's not how hard you work but how you work hard: Evaluating workaholism components. International Journal of Stress Management, 6, 225-239. http://dx.doi.org/10.1023/A:1021936220220

Burke, R. (1999b). Workaholism and extra-work satisfactions. International Journal of Organizational Analysis, 7, 352-364. Retrieved from PsycINFO database. http://dx.doi.org/10.1108/eb028906

Burke, R. (2000). Workaholism and divorce. Psychological Reports, 86(1), 219.

Burke, R. (2001a). Organizational values, work experiences and satisfactions among managerial and professional women. Journal of Management Development, 20, 346-354. http://dx.doi.org/10.1108/02621710110695333

Burke, R. (2001b). Predictors of workaholism components and behaviors. International Journal of Stress Management, 8, 113-127. http://dx.doi.org/10.1023/A:1009577230051

Burke, R. (2001c). Workaholism components, job satisfaction, and career progress. Journal of Applied Social Psychology, 31, 2339-2356. http://dx.doi.org/10.1111/j.1559-1816.2001.tb00179.x

Burke, R. (2001d). Workaholism in organizations: the role of organizational values. Personnel Review, 30, 637-645. http://dx.doi.org/10.1108/EUM0000000005977

Burke, R. (2004). Workaholism, self-esteem, and motives for money. Psychological Reports, 94, 457-463. http://dx.doi.org/10.2466/pr0.94.2.457-463

Burke, R., \& Fiksenbaum, L. (2009). Work motivations, work outcomes, and health: Passion versus addiction. Journal of Business Ethics, 84, 257-263. http://dx.doi.org/10.1007/s10551-008-9697-0

Burke, R., \& Koksal, H. (2002). Workaholism among a sample of Turkish managers and professionals: An exploratory study. Psychological Reports, 91, 60-68. http://dx.doi.org/10.2466/PR0.91.5.60-68 
Burke, R., \& Matthiesen, S. (2004). Short Communication: Workaholism among Norwegian journalists-Antecedents and consequences. Stress and Health: Journal of the International Society for the Investigation of Stress, 20, 301-308. http://dx.doi.org/10.1002/smi.1025

Burke, R., \& Ng, E. (2007). Workaholic behaviors: Do colleagues agree? International Journal of Stress Management, 14, 312-320. http://dx.doi.org/10.1037/1072-5245.14.3.312

Burke, R., Koyuncu, M., \& Fiksenbaum, L. (2008). Workaholism, work and extra-work satisfactions and psychological well-being among professors in Turkey. Cross Cultural Management, 15, 353-366. http://dx.doi.org/10.1108/13527600810914148

Burke, R., Koyuncu, M., Fiksenbaum, L., \& Demirer, H. (2009). Time affluence, material affluence and well-being among Turkish managers. Cross Cultural Management, 16, 386-397. http://dx.doi.org/10.1108/13527600911000357

Burke, R., Matthiesen, S., \& Pallesen, S. (2006). Personality correlates of workaholism. Personality and Individual Differences, 40, 1223-1233. http://dx.doi.org/10.1016/j.paid.2005.10.017

Burke, R., Oberklaid, F., \& Burgess, Z. (2003). Organizational values, work experiences, and satisfactions among Australian psychologists. International Journal of Organizational Analysis, 11, 123-135. Retrieved from PsycINFO database. http://dx.doi.org/10.1108/eb028966

Burke, R., Richardsen, A., \& Mortinussen, M. (2002). Psychometric properties of Spence and Robbins' measures of workaholism components. Psychological Reports, 91, 1098-1104. http://dx.doi.org/10.2466/PR0.91.8.1098-1104.

Burke, R., Richardsen, A., \& Mortinussen, M. (2004). Workaholism among Norwegian managers: Work and well-being outcomes. Journal of Organizational Change Management, 17, 459-470. http://dx.doi.org/10.1108/09534810410554489

Chamberlin, C., \& Zhang, N. (2009). Workaholism, health, and self-acceptance. Journal of Counseling \& Development, 87, 159-169. http://dx.doi.org/10.1002/j.1556-6678.2009.tb00563.x

Clark, L. A. (1993). Manual for the Schedule for Nonadaptive and Adaptive Personality (SNAP). Minneapolis: University of Minnesota Press.

Clark, L. A., Livesley, W. J., Schroeder, M. L., \& Irish, S. L. (1996). Convergence of two systems for assessing specific traits of personality disorder. Psychological Assessment, 8, 294-303. http://dx.doi.org/10.1037/1040-3590.8.3.294

Clark, L.A, McEwen, J.L., Collard, L.M., \& Hickok, L.G. (1993). Symptoms and traits of personality disorder: Two new methods for their assessment. Psychological Assessment, 5, 81-91. http://dx.doi.org/10.1037/1040-3590.5.1.81

Cohen, J. (1988). Statistical power analysis for the behavioral sciences (2nd ed.). Hillsdale, NJ: Lawrence Erlbaum Associates.

Feeney, M., \& Bozeman, B. (2009). Staying late: Comparing work hours in public and nonprofit sectors. The American Review of Public Administration, 39, 457-477. http://dx.doi.org/10.1177/0275074008327293

Galperin, B., \& Burke, R. (2006). Uncovering the relationship between workaholism and workplace destructive and constructive deviance: An exploratory study. The International Journal of Human Resource Management, 17, 331-347. Retrieved from PsycINFO database. http://dx.doi.org/10.1080/09585190500404853

Harpaz, I., \& Snir, R. (2003). Workaholism: Its definition and nature. Human Relations, 56, 291-319. http://dx.doi.org/10.1177/0018726703056003613

Johnstone, A., \& Johnston, L. (2005). The relationship between organizational climate, occupational type and workaholism. New Zealand Journal of Psychology, 34, 181-188.

Kanai, A., \& Wakabayashi, M. (2001). Workaholism among Japanese blue-collar employees. International Journal of Stress Management, 8, 129-145. http://dx.doi.org/10.1023/A:1009529314121

Kanai, A., \& Wakabayashi, M. (2004). Effects of economic environmental changes on job demands and workaholism in Japan. Journal of Organizational Change Management, 17, 537-548. http://dx.doi.org/10.1108/09534810410554533

Liang, Y., \& Chu, C. (2009). Personality traits and personal and organizational inducements: Antecedents of workaholism. Social Behavior and Personality, 37, 645-660. http://dx.doi.org/10.2224/sbp.2009.37.5.645 
Lounsbury, J., Gibson, L., \& Hamrick, F. (2004). The development and validation of a personological measure of work drive. Journal of Business and Psychology, 18, 427-451. http://dx.doi.org/10.1023/B:JOBU.0000028445.29004.d1

Maslach, C., \& Jackson, S. (1984). Burnout in organizational settings. Applied Social Psychology Annual, 5 , 133-153.

McMillan, J., \& Northern, N. (1995). Organizational codependency: The creation and maintenance of closed systems. Management Communication Quarterly, 6-45. http://dx.doi.org/10.1177/0893318995009001002

McMillan, L., \& O'Driscoll, M. (2004). Workaholism and health: Implications for organizations. Journal of Organizational Change Management, 17, 509-519. http://dx.doi.org/10.1108/09534810410554515

McMillan, L., Brady, E., O'Driscoll, M., \& Marsh, N. (2002). A multifaceted validation study of Spence and Robbins' (1992) Workaholism Battery. Journal of Occupational and Organizational Psychology, 75, 357-368. http://dx.doi.org/10.1348/096317902320369758

McMillan, L., O'Driscoll, M., \& Brady, E. (2004). The impact of workaholism on personal relationships. British Journal of Guidance \& Counselling, 32, 171-186. http://dx.doi.org/10.1080/03069880410001697729

McMillan, L., O'Driscoll, M., Marsh, N., \& Brady, E. (2001). Understanding workaholism: Data synthesis, theoretical critique, and future design strategies. International Journal of Stress Management, 8, 69-91. http://dx.doi.org/10.1023/A:1009573129142

Mudrack, P. (2004). Job involvement, obsessive-compulsive personality traits, and workaholic behavioral tendencies. Journal of Organizational Change Management, 17, 490-508. http://dx.doi.org/10.1108/09534810410554506

Mudrack, P., \& Naughton, T. (2001). The assessment of workaholism as behavioral tendencies: Scale development and preliminary empirical testing. International Journal of Stress Management, 8, 93-111. http://dx.doi.org/10.1023/A:1009525213213

Nagy, S., \& Davis, L. (1985). Burnout: A comparative analysis of personality and environmental variables. Psychological Reports, 57, 1319-1326. http://dx.doi.org/10.2466/pr0.1985.57.3f.1319

Ng, T. W. H., Sorensen, K., \& Feldman, D. (2007). Dimensions, antecedents, and consequences of workaholism: A conceptual integration and extension. Journal of Organizational Behavior, 28, 111-136. http://dx.doi.org/10.1002/job.424

Niehuis, S. (2007). Convergent and discriminant validity of the Marital Disillusionment Scale. Psychological Reports, 100, 203-207. http://dx.doi.org/10.2466/PR0.100.1.203-207

Oates, W. (1971). Confessions of a workaholic. New York: World. Retrieved from http://www.oates.org/cos/oateslibrary/books/confessions/weo-coaw-00a.html

Peiperl, M., \& Jones, B. (2001). Workaholics and overworkers: Productivity or pathology? Group \& Organization Management, 26, 369-393. http://dx.doi.org/10.1177/1059601101263007

Piotrowski, C., \& Vodanovich, S. (2006). The interface between workaholism and work-family conflict: A review and conceptual framework. Organization Development Journal, 24, 84-92.

Porter, G. (1996). Organizational impact of workaholism: Suggestions for researching the negative outcomes of excessive work. Journal of Occupational Health Psychology, 1, 70-84. http://dx.doi.org/10.1037/1076-8998.1.1.70

Robinson, B. (1999). The work addiction risk test: Development of a tentative measure of workaholism. Perceptual \& Motor Skills, 88, 199.

Robinson, B. (2000). A typology of workaholics with implications for counselors. Journal of Addictions \& Offender Counseling, 21, 34. http://dx.doi.org/10.1002/j.2161-1874.2000.tb00150.x

Robinson, B. (2000). Workaholism: Bridging the gap between workplace, sociocultural, and family research. Journal of Employment Counseling, 37, 31-47. http://dx.doi.org/10.1002/j.2161-1920.2000.tb01024.x

Robinson, B. (2001). Workaholism and family functioning: A profile of familial relationships, psychological outcomes, and research considerations. Contemporary Family Therapy: An International Journal, 23, 123-135. http://dx.doi.org/10.1023/A:1007880301342 
Robinson, B., \& Carroll, J. (1999). Assessing the offspring of workaholic parents: The Children of Workaholics Screening Test. Perceptual and Motor Skills, 88, 1127-1134.

Robinson, B., Flowers, C., \& Carroll, J. (2001). Work stress and marriage: A theoretical model examining the relationship between workaholism and marital cohesion. International Journal of Stress Management, 8, 165-175. http://dx.doi.org/10.1023/A:1009533415030

Robinson, B., Flowers, C., \& Ng, K. (2006). The relationship between workaholism and marital disaffection: Husbands' perspective. The Family Journal, 14, 213-220. http://dx.doi.org/10.1177/1066480706287269

Robinson, B., \& Post, P. (1997). Risk of addiction to work and family functioning. Psychological Reports, 81, 91.

Salmela-Aro, K., \& Nurmi, J. (2004). Employees' motivational orientation and well-being at work: A person-oriented approach. Journal of Organizational Change Management, 17, 471-489. http://dx.doi.org/10.1108/09534810410554498

Schaufeli, W., Bakker, A., Van der Heijden, F., \& Prins, J. (2009). Workaholism, burnout and well-being among junior doctors: The mediating role of role conflict. Work \& Stress, 23, 155-172. http://dx.doi.org/10.1080/02678370902834021

Schaufeli, W., Taris, T., \& van Rhenen, W. (2008). Workaholism, burnout, and work engagement: Three of a kind or three different kinds of employee well-being? Applied Psychology: An International Review, 57, 173-203. http://dx.doi.org/10.1111/j.1464-0597.2007.00285.x

Scott, K., Moore, K., \& Miceli, M. (1997). An exploration of the meaning and consequences of workaholism. Human Relations, 50, 287-314. http://dx.doi.org/10.1177/001872679705000304

Senholzi, M. (2008). The validation and generalization of the Work Attitudes and Behaviors Inventory (WABI). Dissertation Abstracts International. Retrieved from PsycINFO database.

Smith, B. (2007). Stroking the compulsion to work. Bloomington, IN: AuthorHouse.

Snir, R., \& Zohar, D. (2008). Workaholism as discretionary time investment at work: An experience-sampling study. Applied Psychology: An International Review, 57, 109-127. http://dx.doi.org/10.1111/j.1464-0597.2006.00270.x

Spence, J., \& Robbins, A. (1992). Workaholism: Definition, measurement, and preliminary results. Journal of Personality Assessment, 58, 160-178. http://dx.doi.org/10.1207/s15327752jpa5801_15

Spruell, G. (1987). Work fever. Training \& Development Journal, 41, 41-45.

Srivastava, A., Locke, E., \& Bartol, K. (2001). Money and subjective well-being: It's not the money, it's the motives. Journal of Personality and Social Psychology, 80, 959-971. http://dx.doi.org/10.1037/0022-3514.80.6.959

Taris, T., Beckers, D., Verhoeven, L., Geurts, S., Kompier, M., \& van der Linden, D. (2006). Recovery opportunities, work--home interference, and well-being among managers. European Journal of Work and Organizational Psychology, 15, 139-157. http://dx.doi.org/10.1080/13594320500513889

Taris, T., Schaufeli, W., \& Verhoeven, L. (2005). Workaholism in the Netherlands: Measurement and Implications for Job Strain and Work-Nonwork Conflict. Applied Psychology: An International Review, 54, 37-60. http://dx.doi.org/10.1111/j.1464-0597.2005.00195.x

Taris, T., Schaufeli, W., van Hoogenhuyze, C., \& Zon, A. (2003). Werkverslaving, stress en gezondheid: Ontwikkeling en validatie van eenNederlandseworkaholisme-schaal. English Title: Work addiction, stress and health: Development and validation of a Dutch Workaholism scale. Gedrag \& Gezondheid: Tijdschriftvoor Psychologie en Gezondheid, 31, 2-18.

Vodanovich, S., Piotrowski, C., \& Wallace, J. (2007). The relationship between workaholism and health: A report of negative findings. Organization Development Journal, 25, 70-75. Retrieved from PsycINFO database.

Wittenberg, K., \& Norcross, J. (2001). Practitioner perfectionism: Relationship to ambiguity tolerance and work satisfaction. Journal of Clinical Psychology, 57, 1543-1550. http://dx.doi.org/10.1002/jclp.1116

Studies providing data included in the meta-analysis. 